\title{
THE SPEECH ACTS OF REQUESTING HELP OF JAVANESE PEOPLE IN MALANG, EAST JAVA
}

\author{
Retno Setya Budiasningrum ${ }^{1}$, Rahmi Rosita ${ }^{2}$ \\ Politeknik LP3I Jakarta, Indonesia \\ E-mail : Retnosb18@gmail.com
}

\begin{abstract}
Requesting for help is one of illocutionary acts classified as a directive speech act. It performs by the speaker to get the interlocutor to do something. This study explored the expressions of requesting help used by Javanese people in Malang and the factors that influence them. This study described the speech act are used in asking for help in Javanese in Malang. It also presented the factors that influence these speech acts. The population in this study was the Javanese people in Malang. Some dialogues were taken randomly in different places with participants who have various backgrounds. The patterns of speech acts used in asking for help are very diverse. The factors that influenced their diversity are closeness, position, age, educational background, and norms of politeness.
\end{abstract}

Key words: speech act requesting help, norms in communication, relationship between interlocutors

\section{INTRODUCTION}

Language is the most valuable aspect for humans because they can communicate with one another, exchange opinions, information, knowledge and express feelings. "Through language we plan our lives and remember our past; we exchange ideas and experiences; we form our social and individual identities" (Cook, V. (2013:1). There is no one in this world apart from language. Even in thinking, humans always use language.

All humans become part of a community where language is a means of communicating between members of that community. Hence, it is impossible to separate language and society. "Both have a reciprocal or reciprocal relationship. A good language develops based on a system, namely a set of rules that are obeyed by the user," Siahaan, P. R. A., \& Saragih, E. (2021:1440). In a particular condition, language greatly influences and determines society, especially thinking patterns, perceptions, and ways of getting along; on the contrary, in other cases, society influences and determines language. When communicating with other people, speakers are in circumstances that social factors make the language context have meaning.

Because of the close relationship between the language and the people who use it, it means that language is inseparable from the culture of the people who use it. Malang, located in East Java, has people from various ethnic groups where the tribes and languages used in daily life are Javanese, Madurese, Indonesian or other languages. However, among these languages, the most dominant language used is Javanese. People who come from outside Java also often use Javanese in dealing with other people outside of their tribe, especially with their friends who are indeed Javanese.

"Speech acts have various purposes which identified by considering the context of the speech act, one of which is used for manifesting politeness in language by using some language strategies, but it will reach the implementation when this measurement of the speech act provided in politeness scale," (Alviah, [2014] in Setiani.D ( 2019:3 ). "The Javanese language makes use of distinct speech levels, which means distinct speech codes", (Poedjosoedarmo, S., 2017:1). He also said that the choice of language or speech level is closely related to the choice of the right term of address and the vocative. "Javanese cannot be separated from unggahungguh, politeness, and social status, so that the relationship between speaker and hearer should be considered", (Farahsani, Y., 2017:2).

Asking for help is an event where someone uses a particular speech act. Because language and society are inseparable things, the illocutionary speech act of requesting help will 
not be the same from one society to another. The people of Malang, which are dominated by the Javanese ethnic, will be more or less influenced by Javanese culture in performing this speech act. Therefore, the kinds of utterances of requesting help used by Javanese people in Malang have their characteristic, certainly.

\section{LITERATURE REVIEW}

\section{Speech Acts}

"Speech acts are a part of speech events involving parties who speak in a particular situation and place. This speech event is a series of a number of speech acts that are organized to achieve a goal. With language knowledge and the skill of using this language is markedly marked by the use of rules of communication with someone, about something, at a certain time, somewhere, and certain behavior" (Setiyanti, A., 2020:2). A speech event is an activity of linguistic interactions in producing utterances involving two parties, speakers and interlocutors, based on a particular context or situation (Chaer and Agustina, [2010: 47] in Adhiguna, I. M. P., Susrawan, I. N. A., \& Erawan, D. G. B., 2019:205). According to Austin in Caponetto, L. (2021 :3) speech act is distinguished into three levels, locutionary, illocutionary, and perlocutionary acts. He stated in Rahayu, F. N., Arifin, M. B., \& Ariani, S. (2018:177) that illocutionary act is the act of doing something. Illocutionary act is performed with intended meaning behind the utterance", Rahayu, F. N., Arifin, M. B., \& Ariani, S. (2018:177).

Searle (1976) in Shaari, A. H. (2020:139) classifies illocutionary acts into five categories. They are representatives (or assertives), directives, commissives, expressives, and declarations. According to him, Directives: refers to the act of expressing desire such as requesting, advising, suggesting, commanding, questioning and ordering. Leech (1993) in (Setiyanti, A. (2020:4) added that directive (directives) which is a speech act that is intended by the speaker so that the speech partner performs the actions mentioned in the speech.

Jucker and Taavitsainen (2008) in Zein, S. I. P. (2021:6), "directive speech acts contain a verb, an object, and a requested task performed by the speaker and the hearer". It means that the speakers who use the directive speech act utterances want the hearer to do something for them. According to Yule (2006: 93) in Widodo, S., \& Prabawa, A. H. (2016:3-4)., "directive speech acts are a type of speech act used by speakers to instruct other people to do something. This type of speech act expresses what the speaker wants. These speech acts include: commands, orders, requests, giving suggestions". Moreover, "the types of sentences based on their communicative value may be divided into declarative, imperative, interrogative, exclamative, and empathetic sentences", (Rahardi, [2002: 74) in Amalia, R. M. (2017:69). "In this regard focuses on the relationship between language and act", (Austin [2009] in Bayat, N. (2013:214). According to this, "while using the language people do not produce only an isolated series of sentences, but also perform an action. In other words, by using the language they either do something or make others do something. Thanking, requesting, promising and et al are some of them", (Marquez Reiter, [2000] in Bayat, N. (2013:214).

Taguchi, N. (2006:514-515) defined three main categories of coding system for requests expressions: direct requests, conventional indirect requests, and nonconventional indirect requests. She exclaimed, that a direct request was indicated in the utterance by grammatical, lexical, or semantic items (e.g., "Please lend me a pen."). And she stated that a conventional indirect request expresses the illocutionary force by using fixed linguistic conventions (e.g., "Could you lend me a pen?"). In addition, she remarked that a non-conventional indirect request is expressed by speakers making partial reference to the requested act (e.g., "Do you have a pen?"). According to Oktadistio, F., \& Aziz, M. (2018:61) "Speech acts can be classified into Direct Speech Act and Indirect Speech Act. Furthermore, Yule (1996) in Oktadistio, F., \& Aziz, M. (2018:61) stated "Direct Speech Act will happen if there is direct relationship between the structure and the function of the utterance. Meanwhile, Indirect Speech Acts will happen if there is indirect relationship between the structure and the function of the utterance." For example, when someone says "it's cold outside", the direct speech act of this utterance is to 
inform the hearer about the real conditions outside, but the indirect speech act of this utterance is to request or to give command to close the door, so the cold will not affect the speaker, (Oktadistio, F., \& Aziz, M., 2018:61). The direct request considers the utterances that directly addressed to the hearer about speaker wants. In contrast, as they don't speak directly to the listener about what they want, it belongs to indirect request.

\section{Norms In a Communication}

"Communicative competence is not only about mastery grammatical forms alone and knowing the codes of a language, but it is also about pragmatic competence which is the ability to perform language functions appropriately in a social context ", (Taguchi, N.,2006:514). And Taguchi also said, "Appropriateness of pragmatic performance depends on sufficient linguistic and pragmatic knowledge, as well as on overall strategic capacities to implement the knowledge in communicative interaction".

According to Ting-Toomey, S., \& Dorjee, T., 2018:4, "In order to communicate appropriately and effectively, we have to learn to manage diverse sociocultural identity memberships adaptively. Intercultural and intergroup communication competence involves optimal integration of the necessary identity-sensitive knowledge, ethnorelative attitudes, and adaptive interaction skills. Ethnorelativism means seeing things from the other's cultural perspective, lens, or identity, or at least giving another's perspective courteous consideration as an alternative explanatory option".

In order to communicate effectively, it can be said that every person needs to learn the norms of language. Norms are not just social aspect only. As Nebeska, I. , (2005:199-200) stated, "The norms of language are often regarded as norms of correctness, norms of communication are defined as implicit rules or principles regulating the selection of appropriate communicative (verbal and non-verbal) means with regard to a given community and current situational context. Norms of communication cover both the norms of language and norms of behavior. Norms are connected with the environment/context, with the partners of communication as well as with the goals of communication",

\section{The Relationship Between Interlocutors}

Communication requires an amount of effort in order to achieve mutual understanding between interlocutors. The use of language in a social interaction cannot be separated from the influence of social context and the cultural values that the speakers already have, (Duranti [2000] in Syafruddin, S., 2010:2)

Rahardi (2001) in Eliya, I., \& Zulaeha, I. (2017:288) suggested that the choices pattern of speech code involves two human social dimensions, horizontal dimension and vertical dimension. In horizontal dimension refers to communication between people at the same levels (example: friends), while vertical dimension refers to upward and downward communication that means it happens between people at different levels (example: boss to employee, teacher to student).

\section{RESEARCH METHODOLOGY}

This qualitative study described the directive speech acts used in requesting help by Javanese people in Malang and explained the factors that influenced them when uttered. The participants taken from the Javanese people in Malang came from various backgrounds, and the taken dialogues were from different places, randomly. The data were from the utterances in the conversation between speakers and the hearers.

\section{ANALYSIS DATA AND DISCUSSION}

\section{Analysis data}

The analysis explored the forms of speech act of requesting help in finding the form of speech act (direct or indirect), the pattern, and the factors that influence the use of form of the speech 
act. The underline sentences indicated the speech act of requesting help. the symbols used in this analysis are S (subject), V (verb), N (noun), P1(first-person pronoun), P2 (second-person pronoun), $\mathrm{P} 3$ ( third-person pronoun).

\section{Dialogue 1}

A: "Rek, nyaluk angine" ( guy, give the air [for my tire])

B: "Ngarep opo mburi?" (front or back)

A: "Mburi" (back)

The dialogue was in a small motorbike repair shop. The speaker was a male motorbike rider around thirty-five and the listener was a male motorbike technician around twenty. They didn't have a close relationship. The speaker asked the listener for help directly. Thus, it was classified as a direct speech act. Those factors created the pattern as $\mathrm{S}$ (rek/guy) $+\mathrm{V}$ (nyaluk/give)+ $\mathrm{N}$ (angine / the air [for my tire])

\section{Dialogue 2}

Speaker : Dik, tulung entasono pakeanku ning dhuwur (sis, please get my cloth upstair) Listener : Durung garing ( hasn’t dried yet)

This was a dialogue between an older brother and his younger brother, at home. The closeness did not influence the speech act. The speaker uttered the requesting help directly. Thus, it is classified as direct speech act with the pattern $\mathrm{S}$ (dik/brother)+tulung+V(entas-ono/getono) + adv of place (ning dhuwur/upstair).

\section{Dialogue 3}

Speaker : $\mathrm{Bu}$, tulung klambiku sing batik iki setrikano, kate tak gawe engko bengi neng kondangan

(Mom, please iron my batik shirt, I am going to wear it tonight for a party)

Listener : Lha, wingi koyo-e wes tak setriko, pak. (lho, yesterday it seem I have already ironed it, dear)

Speaker : Opo, wong durung (what, it hasn't ironed yet)

Listener: Yo wes, dekek-en kono engko mari masak tak setrikane. (ok, put in here after cooking I will iron it)

This dialogue was between a husband and his wife. The factors that influence the speech act are the norm of politeness, the level of closeness, the level of position (the speaker is older than the speaker). It was a direct speech act with the pattern $\mathrm{S}(\mathrm{bu} / \mathrm{mom})+$ tulung(please $)+\mathrm{N}(\mathrm{klambi}$ batik/batik shirt)+V-no(setrika-no/iron)+ a reason (kate tak gawe engko bengi neng kondangan/I'm going to wear it tonight for a party).

\section{Dialogue 4}

Speaker : Dik, tulung jupokno sandalku (sis, please get my sandals)

Listener : Ndek endi mbak? (where is it sis?)

Speaker : Iku, ndik ngarep lawang kamarku (that,infront my room door)

It is a dialogue between an older sister and her younger sister, at home. The factors that influence the speech act is the norm of politeness; they had a close relationship; the age and position level of the speaker did not influence the production of this utterance. This request help speech act classification is as a direct speech act with the pattern $\mathrm{S}(\mathrm{dik} / \mathrm{sis}+$ please (tulung)+Vono (jupok-no/get) + N (sandalku/my sandals). 


\section{Dialogue 5}

Speaker : Nduk, aku sesok tanggal 8 arepe nyang Sragen. Kon melok-o yo ewangono ako nggowo dagangan (dear, I am going to Sragen (name of a city in east Java) on the date of eight. You come with me for help me carrying my merchandise)

Listener : kulo sakjane nggih remen, namong tanggal 8 niku kullo tasih wonten ujian ( Actually I like to go with you, but on the date of 8 I still have an examination)

The dialogue was between an aunt and her niece. The influence factor is the norm of politeness. The speaker is older, had a close relationship, and had a higher position, the speaker maintained her utterance by giving a reason why she asked for help. She used direct speech act with the pattern S (nduk/dear + reason (sesok tanggal 8 arepe nyang Sragen/ I am going to Sragen on 8) $+\mathrm{P} 2($ koen/you $)+\mathrm{V} 1$-o $($ melok-o/come $)+\mathrm{V} 2$-ono(ewang-ono/help $)+\mathrm{P} 1(\mathrm{aku} / \mathrm{me})+\mathrm{V} 3$ (nggowo/carry) $+\mathrm{N}$ (daganganku/merchandice) .

\section{Dialogue 6}

Speaker : $\underline{\mathrm{Bu}}$, dalem rodo mboten sekeco, pijeti nggih ( mom, I don't have good condition, give me a massage)

Listener : Iyo, tapi tak cek dhisik segane opo wes mateng (ok, but let me check whether the rice has already cooked)

The dialogue was between a daughter and her mother, at home. The factors that influence the producing utterance of request help were the position of the speaker (she was a daughter) and she was younger; the closeness does not really influence the producing of the speech act. The speaker delivered the request help directly with the pattern as $S$ (bu/mom) +reason ( I don't have a good condition) + V-I (pijet-i/ give a massage) + nggih

\section{Dilaogue 7}

Speaker : Me... koen weruh omahe mba Eni-a ? (Me/ the listener's name you know where miss Eni's house is)

Listener : Weruh... mbiyen aku diajak mbak Eni nang omahe ( I know.. she ever took me to her house)

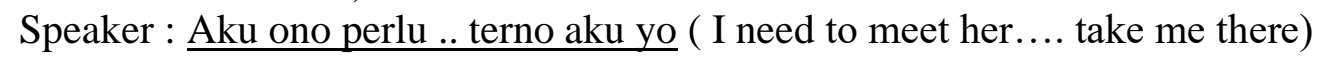

It is a direct speech act. The dialogue was between older and younger sisters, at home. the speaker delivered the speech act using a direct expression with the pattern: reason ( koen weruh omahe mba Eni-a ?you know where miss Eni's house is) + V-no (ter-no/take) + P1 (aku/me) + yo.

\section{Dialogue 8}

Speaker : Urukono Ari matematika, An. (teach Ari math, An/ the listener's name)

Listener : Pundi larene ,bulik? ( where is the boy , aunty? )

Speaker : ndek omah ( at home)

Listener : Oh, inggih kulo mangke teng mriku ( oh, ok I will go there, later )

This is a direct expression. The dialogue was between an aunt and her niece. The speaker was older than the listener but they had a close relationship. Considering the norm of politeness, the speaker used a greeting word at the end of the sentence. Those factors that influence the speech act resulted the pattern $\mathrm{V}$-ono (uruk-ono/teach) $+\mathrm{P} 3$ (Ari/the name of P3) $+\mathrm{N}$ (matematika/math) $+\mathrm{S}$ ( An/ the listener's name). 


\section{Dialogue 9}

Speaker : Terno sampek omah yo, Ar (take me home yo, Ar)

Listener : Tapi aku gak nggowo opo-opo, Lin (but I didn't bring anything)

Speaker : Gak opo-opo, Ar, wis talah. Gelemo wae ( no problem, Ar, it is ok. Come on)

Listener : Yo wis. (ok)

The dialogue was between two female friends. The location was in parking place. The speaker delivered the request help directly. They had the same age. They were close. Those factors resulted in producing the pattern $\mathrm{V}$ - no (ter-no) + destination (sampek omah/to home) + yo $+\mathrm{S}$ (Ar/the listener's name).

\section{Dialogue 10}

Speaker : "Kon weruh aqua ku?" (do you see my mineral water?)

Listener : "Yo weruh lah. Lha iki opo." (Of course I see it. This is it )

The dialogue was between a bus driver as a speaker and his assistant as the listener. The speaker was older than the interlocutor. The expression stated by the speaker was classified as indirect speech act because the speaker didn't directly express a request for help.

\section{Dialogue 11}

Speaker : Ayo Nang, angkat iki ( let's Nang/the listerner's name lift it)

Listener : diangkat kemana? (where do I have to put it ?)

Speaker : Nyang njobo ae ( outside )

The dialogue was between students at a boarding house. They had the same level, same age, and they had a close relationship. These factors resulted the speech act. In this dialogue, the speaker uttered in direct speech act with the pattern ayo $+\mathrm{S}(\mathrm{Nang})+\mathrm{V}$ ( angkat / lift $)+\mathrm{N}$ (iki/it)

\section{Dialogue 12}

Speaker : Mejone ndang selehen njero (put the table inside, right away)

Listener : Kate ono opo (what will happened ?)

Speaker : Ndang lho, kok malah takon-takon ( don’t ask just do it )

This dialogue was between older and younger brothers. It was a direct request help. The factors that influence the speech act were the position of the speaker ( higher), the age ( older), and the closeness. Those factors resulted the pattern $\mathrm{N}$ (mejone/the table) + V-en ( seleh-en/put) + adv of place ( njero / inside).

\section{Dialogue13}

Speaker : Ta, ono korek? (Ta, do you have a matches)

Listener : Nduwe. Opo-a se? ( I have, why?)

Speaker : Nek nduwe, aku njaluk. Aku kate ngrokok gak onok korek ( If you have, give me some. I want to smoke but I don't have a matches)

The dialogue was indirect expression. The speaker was a male employee and the listener was a male students. The influence factors were the closeness and the age ( the speaker was older ).

\section{Dialogue 14}

Speaker : Vi .. rewangia. ( Vi, help )

Listerner : Yo..yo (ok) 
The dialogue was between older and younger brothers, at home. The factor that influence the speech act were the position level of the speaker(higher), the speaker's age (older), and the closeness. The speaker delivered the help expression directly. It resulted the pattern as $\mathrm{S}$ (Vi/listener's name) $+\mathrm{V}$-ia (rewang-ia) .

\section{Dialogue 15}

Speaker : Iki paringono nang mejo, le (put it on the table, son)

Listener : Mesti aku, mas Hari ngono lho ( must I, why not brother Hari )

The dialogue was between a mother and her son. The influence factors were the postion level, the age, and the closeness. The speaker delivered the utterance directly with pattern V-ono (paring-ono/give) + adv of place (neng mejo /on the table)

\section{FINDING}

From the description above, it can be seen that the forms of speech act used in the speech act of asking for help are diverse. They are as follow:

1. $\mathrm{S}+\mathrm{V}+\mathrm{N}$

2. $\mathrm{S}+$ tulung $+\mathrm{V}$-ono $+\mathrm{N}+\mathrm{adv}$ of place

3. $\mathrm{S}+$ tulung $+\mathrm{V}-\mathrm{no}+$ reason

4. $\mathrm{S}+$ tulung $+\mathrm{V}-$ no $+\mathrm{N}$

5. Reason $+\mathrm{V}$-ono $+\mathrm{N}$

6. S+reason $+\mathrm{V}-\mathrm{i}+$ nggih

7. $\mathrm{V}-\mathrm{o}+\mathrm{P} 1+\mathrm{yo}$

8. $\mathrm{V}-\mathrm{ono}+\mathrm{P} 3+\mathrm{N}$

9. V-no+adv of place

10. Indirect

11. $\mathrm{S}+\mathrm{V}+\mathrm{N}$

12. $\mathrm{N}+\mathrm{V}-\mathrm{en}+\mathrm{adv}$ of place

13. Indirect

14. $\mathrm{S}+\mathrm{V}-\mathrm{ia}$

15. $\mathrm{S}+\mathrm{V}-\mathrm{ono}+\mathrm{adv}$ of place

The factors that influence the use of this speech act are closeness, social level, age, educational background and occupation background. These factors cannot stand independently; they influence each other. As an example, V-no in dialogue 2, age, social level and closeness produce pattern $\mathrm{V}$-ono+N together.

The speakers mostly use patterns V-no and V-ono to express requests for help because they have a higher position than the speaking partner. It does not make any difference whether they have a good relationship or not. According to the norm, a speaker whose relationship does not close with the listener should declare a polite speech act. However, many speakers with the higher level and no close relationship utter their request help with pattern V-no or V-ono. Speaker with higher position and has a close relationship with the hearer may utter requesting help in pattern $\mathrm{S}+\mathrm{V}-$-no/ono+N. Considering the norm of politeness, they deliver their request help with more polite expression. The speakers use pattern $\mathrm{S}+$ tulung(please) $+\mathrm{V}$-ono+N in their requests help, as in dialogue $2,3,4$. In dialogue 3 and 6 , they mention a reason why the speakers mention a reason why they ask for help, as well.

Some speakers deliver their request help expression in indirect; they do it to show politeness. It shows in dialogue 10 and 13. The description shows that there are various speech acts used by Javanese people in Malang to ask for help. These utterances are created by the influence of factors of closeness, level of position, age, work and educational background, where these factors cannot stand alone but have an interdependent relationship. 
The norms in Javanese society in general, such as the norms of politeness and respect for others, also affect the form of speech used, but it seems that the level of closeness affects it a lot. People in Malang also have their own characteristics in using speech acts asking for help; they use more direct speech. The aspect that may influence the character of the people. They are more open compared to Javanese people in other areas. We can see from the finding that language used by society is inseparable from the structure and culture of the user community.

\section{REFERENCES}

Adhiguna, I. M. P., Susrawan, I. N. A., \& Erawan, D. G. B. (2019). Analisis Tindak Tutur Lokusi, Ilokusi, dan Perlokusi dalam Proses Pembelajaran Bahasa Indonesia di Kelas XI MIPA 7 SMA N 7 Denpasar Tahun Pelajaran 2018/2019. Jurnal Bakti Saraswati (JBS): Media Publikasi Penelitian dan Penerapan Ipteks, 8(2), 204-211.

Amalia, R. M. (2017). Use of implicit performative utterances at University of Padjadjaran and at University of Pennsylvania. Studies in English Language and Education, 4(1), 66-75.

Bayat, N. (2013). A study on the use of speech acts. Procedia-social and behavioral sciences, 70, 213-221.

Candra, Y. A., Fitriana, A., \& Puspitorini, D. (2019). Personal Pronouns as the Constructor of Speaker Identity: Analysis in Javanese Text.

Caponetto, L. (2021). A Comprehensive Definition of Illocutionary Silencing. Topoi, 40(1), 191-202.

Cook, V. (2013). Second language learning and language teaching. Routledge.

Eliya, I., \& Zulaeha, I. (2017). Pola komunikasi politik ganjar pranowo dalam perspektif sosiolinguistik di media sosial instagram. Seloka: Jurnal Pendidikan Bahasa Dan Sastra Indonesia, 6(3), 286-296.

Farahsani, Y. (2017). The Implementation of Poltness Principle by Javanese People: A Cultural Pragmatic Study. International Journal of Novel Research in Humanity and Social Sciences, 4(1), 1-5.

Nebeska, I. (2005). On the norms of communication. Prague: Charles University.

Oktadistio, F., \& Aziz, M. (2018). An Analysis Of Direct And Indirect Speech Acts Performed By Main Character In The Movie Revenant Script. Journal of English Education and Teaching, 2(1), 59-67.

Poedjosoedarmo, S. (2017). Language propriety in Javanese. Journal of Language and Literature, 17(1), 1-9.

Saifudin, A. (2019). Teori Tindak Tutur dalam Studi Linguistik Pragmatik. Lite: Jurnal Bahasa, Sastra, dan Budaya, 15(1), 1-16.

Setiani, D. (2019). Strategi Tindak Tutur Ilokusi Dan Tingkat Kesantunan Dalam Nyanyian Suporter Sepak Bola Di Indonesia (Kajian Pragmatik) (Doctoral dissertation, Universitas Pendidikan Indonesia).

Setiyanti, A. (2020). Javanese Language Speech and the development of Javanese language varieties: Tracing the locus, illocutionary and Perlocution in Legi Market Ponorogo. Emanasi: Jurnal Ilmu Keislaman dan Sosial, 3(2).

Siahaan, P. R. A., \& Saragih, E. (2021). Student Actions in the Learning Process of Indonesian Language Subjects and Their Implications for Improving Discussion Ability. Budapest International Research and Critics Institute (BIRCI-Journal): Humanities and Social Sciences, 4(1), 1440-1448.

Subroto, D. E., Rahardjo, M. D., \& Setiawan, B. (2008). Endangered krama and krama Inggil varieties of the Javanese language. Linguistik Indonesia, 26(1), 89-96. 
Sundari, W. (2019). Preserving Javanese Culture by Junior Highschool Students in Northern Semarang District as Javanese Language Environment to Promote Local Tourism Industry. In E3S Web of Conferences (Vol. 125, p. 09019). EDP Sciences.

Syafruddin, S. (2010). Kesantunan Honorifik dalam Tindak Direktif Berbahasa Indonesia Keluarga Terpelajar Masyarakat Tutur Makassar di Kabupaten Gowa. DISERTASI dan TESIS Program Pascasarjana UM.

Taguchi, N. (2006). Analysis of appropriateness in a speech act of request in L2 English. Pragmatics, 16(4), 513-533.

Ting-Toomey, S., \& Dorjee, T. (2019). Communicating across cultures. New York : Guilford Publications .

Widodo, S., \& Prabawa, A. H. (2016). Tindak Tutur Direktif Dan Ekspresif Surat Kabar Harian Kompas Kolom Surat Kepada Redaksi Edisi Februari-Maret 2016 Dan Implementasinya Pada Pembelajaran Bahasa (Doctoral dissertation, Universitas Muhammadiyah Surakarta). 